\title{
TEMPERATURE VARIATIONS AS EVIDENCE OF CLIMATE CHANGE IN NORTHERN NIGERIA
}

\author{
* Luka Fitto Buba and Ahmed Maigari Ibrahim \\ Department of Environmental Management, Bayero University Kano \\ *Correspondence author: Ifbuba454@gmail.com
}

\section{ABSTRACT}

The paper seeks to investigate whether evolving temperature patterns over northern Nigeria agree with the projections made by global warming and climate change models. The data used are screen air temperature on a monthly time scale. These data were obtained from the database of the Nigerian Meteorological Agency (NIMET). The location of the stations adequately represents a fair coverage of the study area. Descriptive statistics of the long-term characteristics of temperature were computed for all the stations. Dispersion and variability indices (standard deviation and coefficient of variation) were also calculated for all the sampled stations. The derived long-term properties of temperature for the region were mapped out using Geographic Information System (GIS) software. Computer-generated graphs were also plotted for the long-term monthly as well as seasonal/annual temperature characteristics. Furthermore, temperature Anomaly values were computed for all the stations. Time series for each station as well as regionally averaged values for the respective ecological zones were plotted in order to present the inter-annual characteristics of temperature for the study area. Trends and discontinuities in temperature time series for northern Nigeria were analyzed using 5-year moving averages and regression. Results obtained from the study indicates variability in annual temperature totals is lower than those of monthly totals; temperature time series present an irregular increase; annual temperature is characterized by a quasi-generalized increase for all stations and a general increase in temperatures for all stations since the 1950s. This increase related to observations at the regional scale were also compared with the IPCC temperature models. The results obtained were found to have similar trends with those of the models. This serves as a pointer to the existence of global warming and climate change phenomenon in northern Nigeria. The study recommends that further research directed at addressing gaps in existing knowledge on global warming and climate change should be encouraged as this would reduce uncertainties and thus facilitate informed decision-making related to issues bordering on climate change.

Key words: Dispersion, inter-annual, long-term, temperature, variability

\section{INTRODUCTION}

Global warming has become familiar to many people as one of the important environmental issues of our day. Many opinions have been expressed concerning it, from the doom-laden to the dismissive. According There is new and stronger evidence that most of the warming over the last 50 years is attributable to human activities. Human activities have altered the chemical composition of the atmosphere through the buildup of greenhouse gases - primarily carbon dioxide, methane, and nitrous oxide. The heattrapping property of these gases is undisputed although uncertaintiesexist about how exactly the earth's climate responds to them. (Houghton, 2004)

Energy from the sun drives the earth's weather and climate, and heats the earth's surface; in turn, the earth radiates energy back into space. Atmospheric greenhouse gases (water vapor, carbon dioxide, and other gases) trap some of the outgoing energy, retaining heat somewhat like the glass panels of a greenhouse. Without this natural "greenhouse effect," temperatures would be much lower than they are now, and life as known today would not be possible. Instead, thanks to greenhouse gases, the earth's average temperature is a more hospitable $15.6^{\circ} \mathrm{C}$. However, problems are certain to arise when the atmospheric concentration of greenhouse gases increases beyond the normal. (IPCC, 2007)

Since the beginning of the industrial revolution, atmospheric concentrations of carbon dioxide have increased nearly $30 \%$, methane concentrations have more than doubled, and nitrous oxide concentrations have risen by about $15 \%$. These increases have enhanced the heat-trapping capability of the earth's atmosphere. Sulfate aerosols, a common air pollutant, cool the atmosphere by reflecting light back into space; however, sulfates are short-lived in the atmosphere and vary regionally (IPCC, 2007).

Scientists generally believe that the combustion of fossil fuels and other human activities are the primary reasons for the increased concentration of carbon dioxide. Plant respiration and the decomposition of organic matter release more than 10 times the $\mathrm{CO}_{2}$ released by human activities; but these releases have generally been in balance during the centuries before industrial revolution with carbon dioxide absorbed by terrestrial vegetation and the oceans. What has changed in the last few hundred years is the additional release of carbon dioxide by human activities.Fossil fuels burned to run cars and trucks, heat homes and businesses, and power factories are responsible for 
Bajopas Volume 10 Number 2 December, 2017

about $98 \%$ of the U.S. emissions of carbon dioxide, $24 \%$ of methane, and $18 \%$ of nitrous oxide (IPCC, 2007). Increased agriculture, deforestation, landfills, industrial production, and mining also contribute a significant share of emissions. In 1997, the United States emitted about one-fifth of the total global greenhouse gases.

The single clearest conclusion emerging from the literature is that Regional climate models for West Africa are still inadequate to predict the impact of increased temperature on rainfall with any accuracy. Key analysts and reviewers (Hulme 2001, Brooks 2004) conclude that it is unwise to predict regional trends with any confidence based on current climate models. At the same time, numerous studies have asserted that the Region will either become hotter and wetter or hotter and drier as a result of global warming. Jones (2005) gives a useful overview of the problems (and possible solutions) associate $\mathrm{d}$ with modeling local climate change in Africa.

It can be safely assumed that the atmospheric concentration of greenhouse gases, notably carbon dioxide, will continue to rise during this century and that there will be associated climate changes of some sort. Hulme et al (2001), using a range of green house gas emission rates and other variables, generated continental scenarios ranging from increases of $0.2^{\circ} \mathrm{C}$ to over $0.5^{\circ} \mathrm{C}$ per decade. Thus by 2100 Africa could on average be from $2^{\circ} \mathrm{C}$ to $6^{\circ} \mathrm{C}$ hotter than present. This projected range of increased temperature, resulting from anthropogenic green house gas emissions, is now almost universally accepted (IPCC 2000, 2001) and (Brooks 2004).

Despite the relative scarcity of impact models for Africa, it seems likely that global warming will have many detrimental effects within the continent, particularly regarding agricultural systems. Traditional systems in Africa have developed strategies to cope with the extremities of existing climatic variability. In many cases, however, these systems are, and will continue, to strain under the pressures of economic development and population growth, as well as from the threats of global warming.

This paper investigates the rate at which near-surface temperature is increasing over northern Nigeria. It also wishes to highlight the main features of temperature variation in northern Nigeria with a view to establishing relationships between the patterns they present and those suggested by climate change models.

\section{MATERIALS AND METHODS}

Data used for this study were obtained from the archives of the Nigerian Meteorological Agency (NIMET). The data consist of monthly rainfall records dating back to the inception of the meteorological stations in northern Nigeria. Twenty stations were considered (see Figure 1). The location of the stations adequately represents a fair coverage of the study area and its regional climate patterns. The data used provides successive climatological 'normal' periods in accordance with the World Meteorological Organization (WMO) standard. Temperature records available in all the stations considered are for the period $1943-2000$. The period covered by the study therefore vary from one station to the other as dictated by the amount of data available in the respective stations. Soft copies of data were obtained, hence eliminating data transfer errors.

Descriptive statistics of the long-term monthly temperature were computed for all the stations studied. Long-term annual mean temperature was also computed for the each of the sampled stations. Subsequently, the standard deviation (a measure of dispersion) and coefficient of variation (measure of variability) were computed for each station. The longterm mean monthly temperature values were used to generate a graphic map showing the main features of temperatureover northern Nigeria (see Figure 1). Furthermore, the long-term monthly averages of temperaturewere tabled according to the location of the meteorological station by ecological zones covering the study area. A graph was also plotted (Figure 2) to illustrate the statio-temporal characteristics of temperatureover the region. All these were done in order to facilitate the understanding of spatial and temporal temperature variations in northern Nigeria.

Inter-annual temperature anomaly indices were computed for each station running through the entire data length of the sampled stations. These were used inconstructing temperature time series for eachstation. This made possible the presentation of inter-annual characteristics of temperature for the study area. Temperature anomalies were expressed as departure from the long-term mean divided by the standard deviation (Figure 3). In addition, five-year moving averages of the anomalies were computed for rainfall and temperature at each of the stations studied. Thesewere superimposed on the time series in order to enhance the identification of fluctuations in the inter-annual behavior of temperature and rainfall for the respective locations.Furthermore, regression analysis was used with a view to establishing linear trends in the behavior of temperature. This made possible the superimposition of regression lines on the individual time series to provide further insight into the direction and strength of trends in the distributions. The coefficients of determination were also computed, to provide a basis for the trends observed and their time dependent behavior at the respective stations. Finally, regionally averaged temperature indices were computed for the respective ecological zones in northern Nigeria. This brought out the behavior of temperature in terms of itsspatiotemporal variation over the study area.

\section{RESULTS AND DISCUSSION}

This section highlightsvariations, fluctuations and possible changes in temperature characteristics in northern Nigeria on seasonal and annual time scales. In particular, it assesses whether the general increase in temperature as predicted by most global warming and climate change models is evident in some or all parts of the study area. The spatial organization of the temperature variations and changes are also discussed, with the aim of assessing the part played by regional and local geographic factors. The chapter is divided into two sections. In the first part, spatiotemporal behavior of temperature is analyzed.The second part examines the issue of temperature anomaly over northern Nigeria. 


\section{Spatio-temporal Temperature Variations}

This deals with on climate variability on the basis of temperature considerations. In the analysis of climate, long-term mean monthly temperatures are considered. The contemporary climate pattern is first characterized as a norm against which variability could be measured (Figures 2). Next, the climate variability is presented in terms of monthly mean temperature for locations representative of the main climatic zones in northern Nigeria.

Figure 1 presents an overview of temperature distribution over northern Nigeria. It shows that temperature distribution over the region closely follows the seasonal migratory pattern of the overhead sun. The main feature is that seasonal temperature values range between $21^{\circ} \mathrm{C}$ and $33{ }^{\circ} \mathrm{C}$. The annual temperature range is small. However, a weak spatial variability could be observed. Seasonal average temperatures in the Sudano-Sahelian Zone do not differ markedly; $22^{\circ} \mathrm{C}$ to $25^{\circ} \mathrm{C}$ for December, January and February; $23^{\circ} \mathrm{C}$ to $30^{\circ} \mathrm{C}$ for March, April and May; $26^{\circ} \mathrm{C}$ to $30^{\circ} \mathrm{C}$ for June, July and Augst; and $25^{\circ} \mathrm{C}$ to $27^{\circ} \mathrm{C}$ for September, October and November. Similar arrangements were observed in the Northern and Southern Guinea Ecological Zones. It was however noted that variability in temperature becomes even less marked in the Guinea Ecological Zones. That is to say, temperature variations increase with latitude.

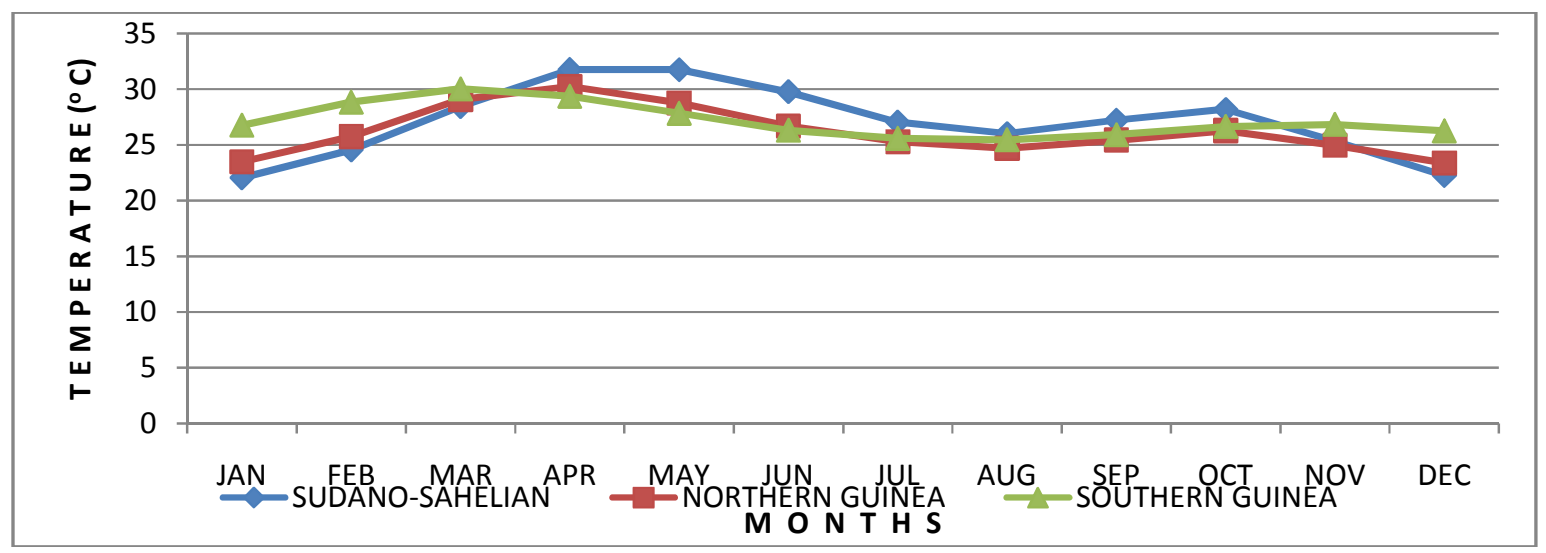

Figure 1: Seasonal Temperature Fluctuation over northern Nigeria.

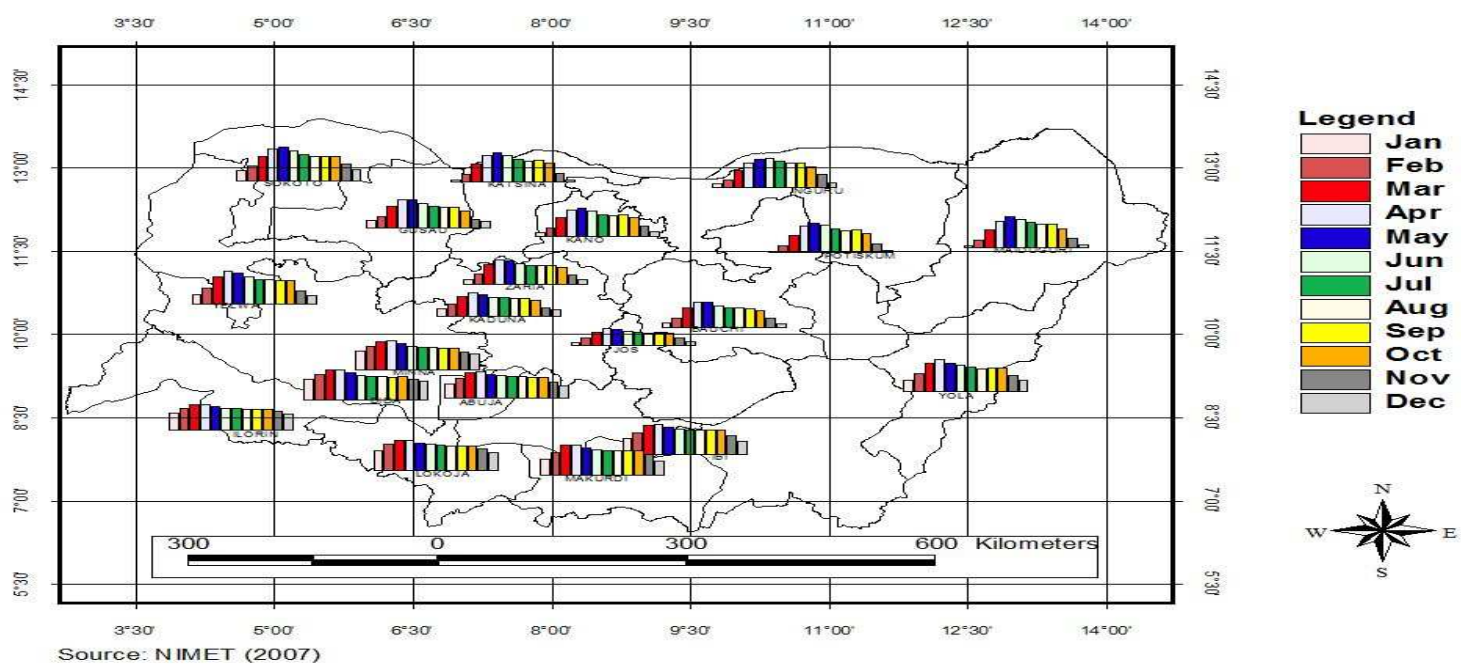

Figure : Long-term Mean Monthly Temperature Ditribution for some Stations in Northern Nigeria

Figure 2: Long-term Mean Temperature Distribution over northern Nigeria.

\section{Regional Temperature Characteristics}

For the characterization of the climate of northern Nigeria, the ecological zones as outlined in table 1 was adopted. Mean monthly maximum temperature varies between $29^{\circ} \mathrm{C}$ and $40^{\circ} \mathrm{C}$. In the Guinea Savanna mean monthly maximum temperature is lowest at about $29^{\circ} \mathrm{Cand}$ highest in April at around $36^{\circ} \mathrm{C}$.
However, the mean maximum temperatures are higher in the Sudano-Sahelian zone than what they are in the Guinea Savanna varying between $30^{\circ} \mathrm{C}$ and $40^{\circ} \mathrm{C}$. The highest maximum temperatures for this zone are recorded in May, while the lowest maximum temperatures are experienced in December and January. 
Bajopas Volume 10 Number 2 December, 2017

Minimum temperatures are on the average about $10^{\circ} \mathrm{C}$ lower than the maximum temperatures in the southern Guinea ecological zone, varying between $19^{\circ} \mathrm{C}$ in January and $24^{\circ} \mathrm{C}$ in April. Differences between minimum temperature and maximum temperatures are approximately $14^{\circ} \mathrm{C}$ in the northern Guinea ecological zone. In the Sudano-Sahelian zone, the difference between minimum and maximum temperatures average about $26^{\circ} \mathrm{C}$. The lowest minimum monthly temperature, for January, of $13^{\circ} \mathrm{C}$ is compared to the lowest mean maximum temperature of $29^{\circ} \mathrm{C}$, which is for January. For the same zone, the highest mean maximum which occur in May and April, are respectively, $25^{\circ} \mathrm{C}$ and $40^{\circ} \mathrm{C}$. All these go to confirm the well known fact that diurnal variations in temperature are more pronounced than inter-annual variations and the usual conceptualization of the night as the winter of the Tropics.

A closer look at Table 1 reveals that among the stations within the Sudano-Sahelian zone, Nguru has the highest temperature variation with a standard deviation of 2.75 and $10 \%$ coefficient of variation. This situation can simply be explained by the location of the station in the Sahel and influenced by the effect of continentality. In the Northern Guinea ecological zone, temperatures are generally characterized by low variability with Kaduna having the lowest values of 0.49 and $2 \%$ standard deviation and coefficient of variation respectively. Yola however, has the highest temperature variation with a 2.29 standard deviation and $8 \%$ coefficient of variation. This situation may not be unconnected with its location within the Benue trough. The Southern Guinea ecological zone also presents a homogeneous temperature pattern, except for Ilorin that has a standard deviation of 5.77 and a coefficient of variation of $24 \%$. Such high values may be connected with local factors that are not readily clear at the moment. A special note was also made of the Abuja values. Instrument data for the station only dates back to 1982 , therefore a climatological normal has not yet been attain. For this reason, not conclusion can be drawn on the variability status of the station.

Table 1: Descriptive Statistics of Temperature over Northern Nigeria

\begin{tabular}{llccc}
\hline Climate Zones & Climate Station & Mean $\left.\mathbf{~}^{\mathbf{}} \mathbf{C}\right)$ & Standard Deviation & Coefficient of Variation \\
\hline Sudano-Sahelian & Sokoto & 28.18 & 0.85 & 3 \\
& Katsina & 26.31 & 0.80 & 10 \\
& Nguru & 26.47 & 2.75 & 5 \\
& Maiduguri & 26.93 & 1.51 & 9 \\
& Potiskum & 27.07 & 2.47 & 3 \\
& Kano & 26.34 & 0.93 & 2 \\
Northern Guinea & Yelwa & 27.71 & 0.54 & 2 \\
& Gusau & 26.54 & 0.56 & 2 \\
& Zaria & 25.28 & 0.50 & 2 \\
& Kaduna & 25.08 & 0.49 & 3 \\
& Bauchi & 25.54 & 0.89 & 3 \\
& Jos & 21.97 & 0.64 & 2 \\
Youthern Guinea & Minna & 27.86 & 2.29 & 5 \\
& Abuja & 27.35 & 0.60 & 2 \\
& Bida & 26.58 & 37.31 & 6 \\
& Ibi & 28.19 & 0.58 & 24 \\
& Ilorin & 27.01 & 1.64 & 2 \\
& Lokoja & 24.33 & 5.77 & 4 \\
\hline
\end{tabular}

Inter-annual variation of maximum temperatures depicted by Table 1 is low in most of the stations across the ecological zones. The implication is that each year is very much like the other with respect to daytime temperatures. The monotony of high daytime temperatures from month to month and from year to year is a well known feature of tropical climates. This notwithstanding, one could identify temporal and spatial patterns in variability of mean monthly maximum temperatures. In the Guinea ecological zones variability is relatively low compared to the Sudano-Sahelian zone (Figure 2). In the more northern zones, coefficients of variability appear to be relatively higher in the months of December, January and February compared to other months of the year. The coefficients of variability reveal a clear contrast between December to March on the one hand and the rest of the year on the other hand. In almost all the stations, the highest coefficients are for January followed by December. This pattern is much more pronounced in the northern areas. Generally low variability of temperature highlighted explains the usual relegation of temperature parameters in the literature on climate variability in the Tropical areas, with more emphasis placed on rainfall which for all intent and purposes characterized by wider variability.

\section{Temperature Anomaly Trends by stations}

Temperature Anomaly time series were plotted for the sampled stations (see Figure 4). This makes it possible to assess the level of inter-annual fluctuation in each station's temperature. The general trends in temperature were assessed using the simple regression analysis technique. The dominance of negative signs is indicative of a general trend towards below normal temperature distribution, while positive signs points to above normal temperature conditions. 
Bajopas Volume 10 Number 2 December, 2017

The results are presented on the time series, in conjunction with the running means, line of least squares and their equation. The trend investigated with the simple regression analysis is a straight line, which gives the impression of continuous and regular increase in temperature. However in reality, the actual annual values fluctuate around the straight line to which the series have been fitted. The analysis gives a general direction of change, which in this case is increasing temperature. The yearly fluctuations may at first appear irregular or random. Further investigation of the series with the technique of fiveyear running mean indicate a tendency for periods of below normal to alternate with periods of above temperature whether in terms of the annual temperature or in terms of any of the components of seasonal temperature. Figure 4.5 exemplifies the fiveyear moving average curves for the temperature series of northern Nigerian meteorological stations.

The evolution of average annual temperature anomalies (Figure 3) shows two main periods over northern Nigeria. The 1950s and 1960s are characterized by negative anomalies. The 1980s are marked by positive anomalies across the entire study area. The last decade (1990s) has shown more marked positive anomalies. This goes to show that temperature distribution over the study area was normally distributed until fairly recent when it began to manifest an upward trend in response to the ongoing global warming phenomenon. The rates of increase vary from station to station. Most of the stations show clearly that temperature is increasing except for Nguru and Jos. Temperatures at Nguru in the 1980s were quite lower than usual, but in the 1990 s, temperature anomaly went back to the positive side. In fact temperature anomaly for the station has more often than not been in the positive for the period considered (1942 - 1998). If that is anything to go by, it can safely be said that the station still responds positively to the global warming predictions for the region, but at slower rate. This situation may be associated with local geographic factors associated with the Sahelian location of Nguru.
In the case of Jos, there tends to be clear descending trend temperature distribution. The situation seems to be the opposite of what is tenable in the other stations in the region. This may not be unconnected with the location of Jos on the plateau that gives it this unique feature since elevation is always associated with decrease in temperature due to the effect of the lapse rate. Another station with somewhat unique feature is Ilorin, with a high negative anomaly in the 1960s that seem to affect the rate of temperature increase. However, the fact remains that temperature at the station is still characterized by rising trend in response to global warming.

Two periods clearly characterize the recent temperature evolution of northern Nigeria: pre- and post 1970. The first period reveals a temperature decrease or low temperatures. The second period is generally marked by warmer temperatures.

Figure 2 comprise regionally average temperature anomaly time series. It presents a spatio-temporal perspective of temperature distribution over the study area. It summarizes the Interannual features of temperature for the three ecological zones making up northern Nigeria. In addition, it also highlights spatial variation of temperature among the respective ecological zones.

Time series for the three ecological zones exhibit a general upward trend in inter-annual temperature values. It is further noted that significant temperature rise commenced in the 1970s and has maintained steady increase. This indicates a positive response to the global warming phenomenon. Prior to the $1970 \mathrm{~s}$, temperature over northern Nigeria fluctuated, with mostly negative anomalies. The situation in the northern guinea zone is however different with both positive and negative anomalies alternating. Since the 1970s, all the ecological zones exhibit similar patterns of response to global warming in their temperature distribution, with a clear increase throughout the region.

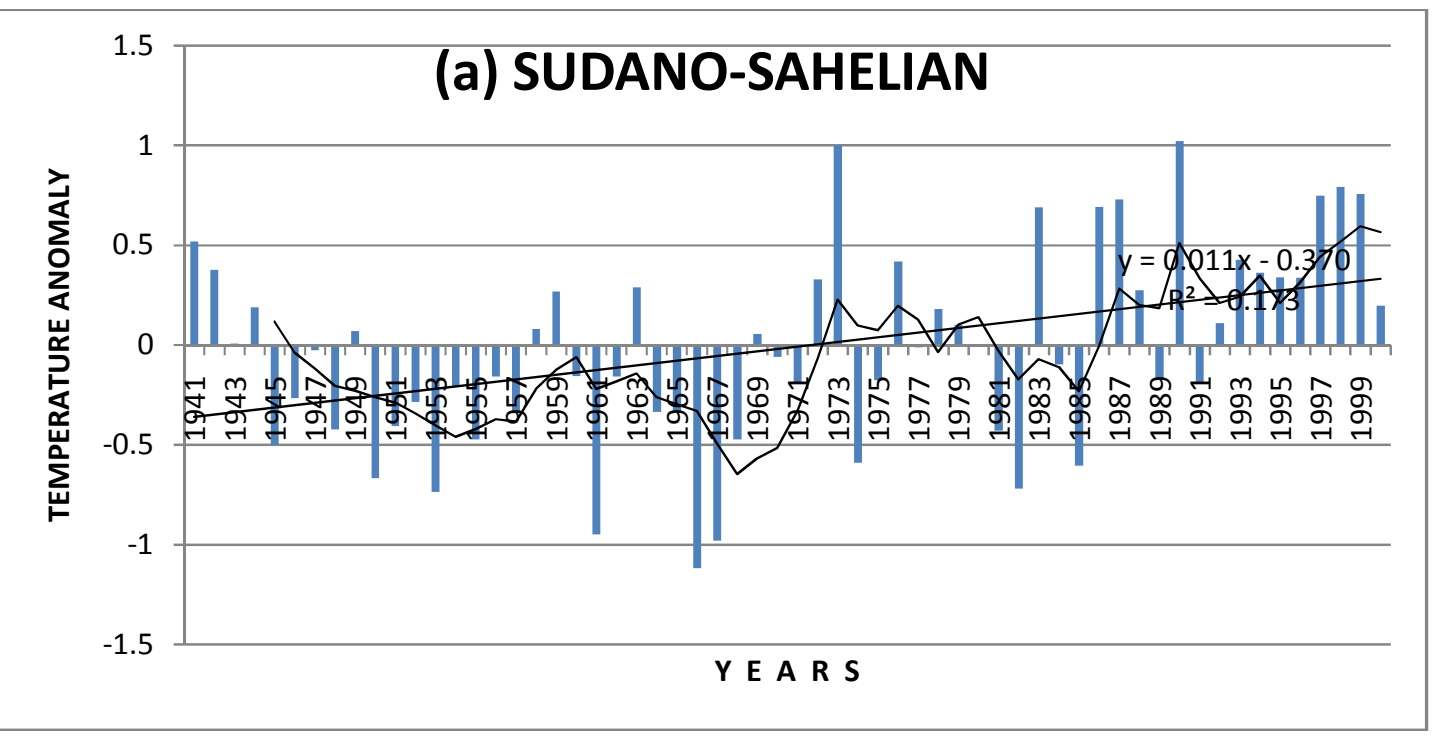




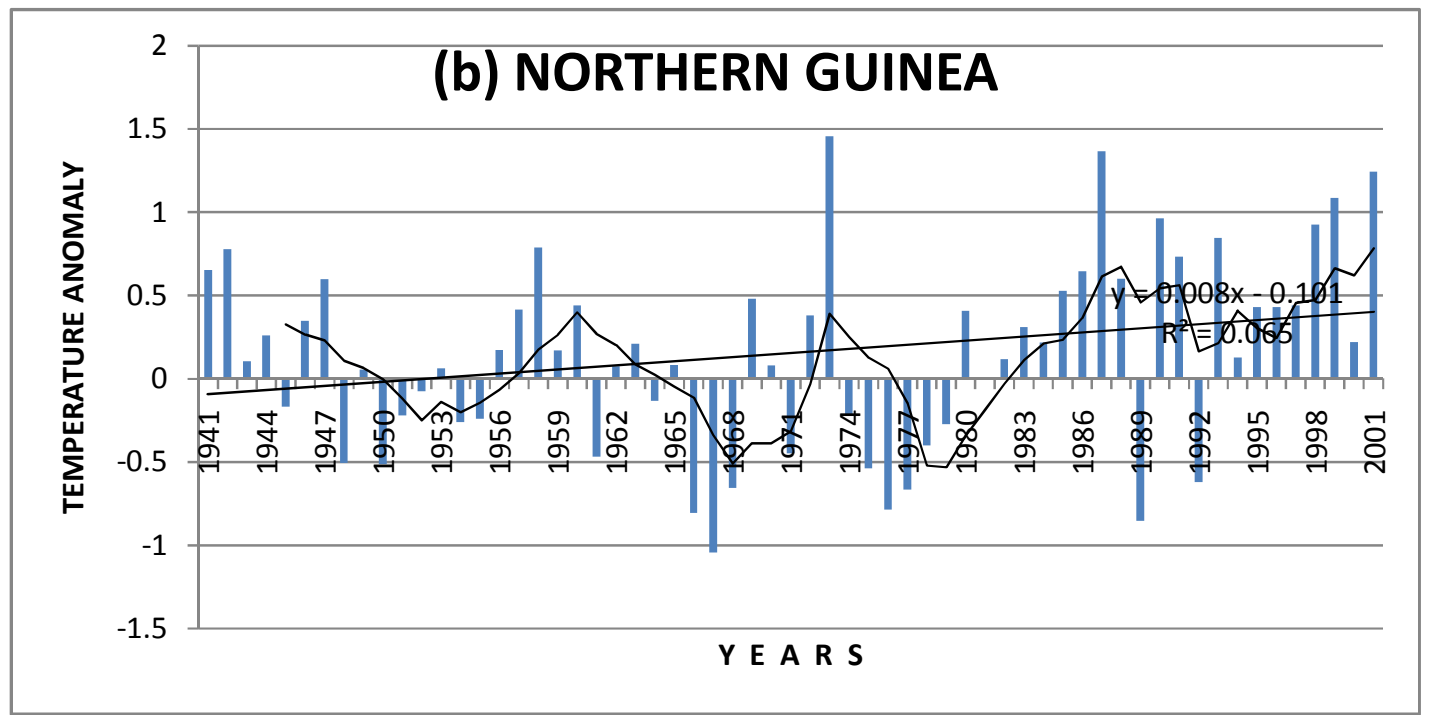

Figure 3: Regional Averaged Temperature Anomaly for northern Nigeria

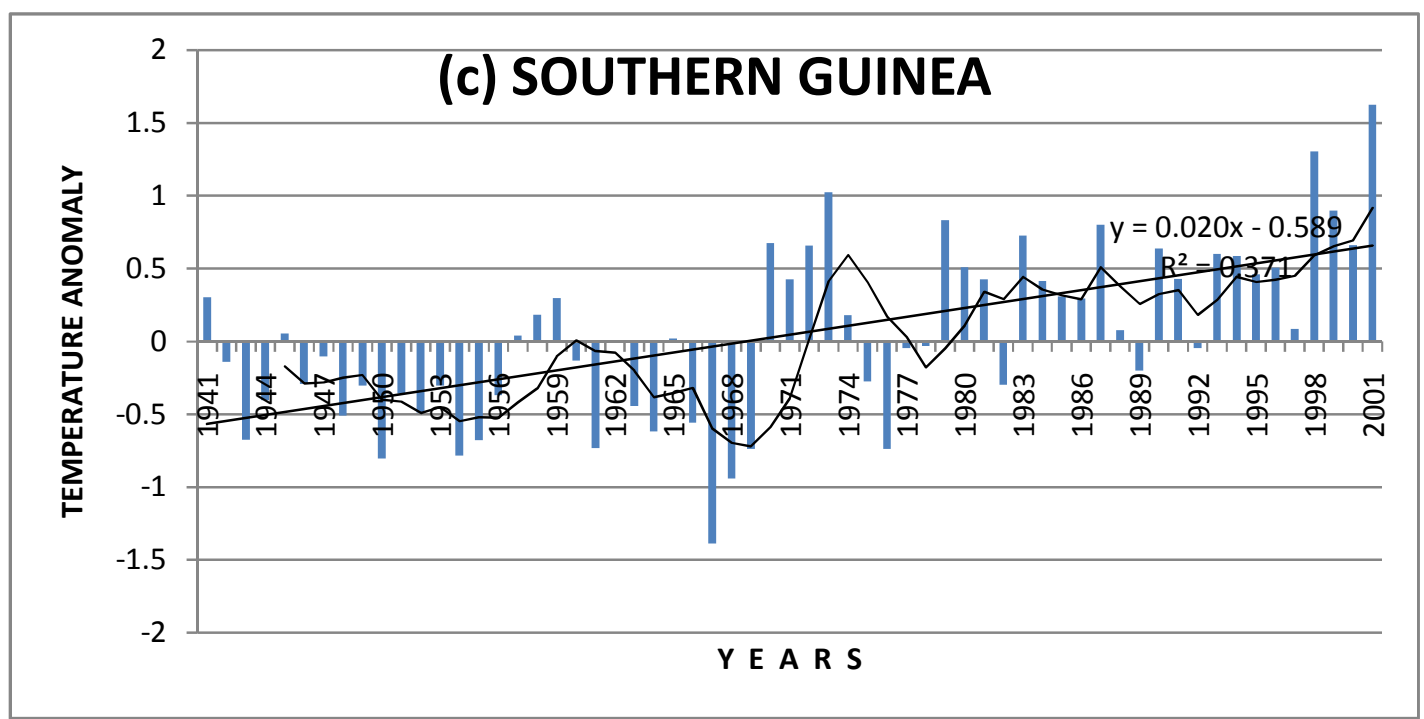

Figure 3: Regional Averaged Temperature Anomaly for northern Nigeria cont.

\section{DISCUSSION}

Temperature evolution over northern Nigeria has been characterized by a warming during the last two decades after a long period of moderate temperatures. In this evolution of temperatures in the study area, there are urban zones which have experienced marked warming, without any doubt linked to urbanization. However, even weak urbanization zones have experienced a general increase in temperatures, an indication of the sensitivity of northern Nigeria to global climate change. This position agrees with those of Adejowon (2006) Houghton (2004), IPCC (2007) Buba (2014).

\section{CONCLUSION}

It can safely be concluded that temperature patterns in northern Nigeria largely conforms to the predictions of the IPCC (2007) model in the following ways:There has been a general increase in temperatures for all stations since the 1950s; the annual temperature is characterized by a quasi-generalized increase for all stations; temperature seem to be on the increase from the 1990s.Although stations sampled are not very dense, the methods adopted for the analysis of data generated has proved appropriate in identifying the trends, anomalies and variations in temperature characteristics over the study area. This position agrees with the submissions of the scientific community in general and the IPCC in particular, pointing to the reality of rising temperatures, warming and climate change.

Contribution of Authors

Luka Fitto Buba collected, analysed and wrote sections of the manuscript, while Ahmed Maigari Ibrahim worked on the layoue and referencing. 
Bajopas Volume 10 Number 2 December, 2017

\section{REFERENCES}

Adejuwon, J.O., Odekunle, T.O. and Adejuwon, S.A. (2006). Climate Variability in Nigeria. In Adejuwon, J.O. and Ogunkoya, O.O. (2006). (Ed.) Climate Change and Food Security in Nigeria.ObafemiAwolowo University Press.

Anderssen, L., J.Wilk, M.C. Todd, D.A. Hughes,A. Earle, D. Kniveton, R. Layberry, Arnell, N.W., 2004: Climate change and global water resources: SRES emissions and socioeconomic scenarios. Global Environ. Chang., 14, 31-52.

Awosika, L.F., G.T. French, R.T. Nicholls, and C.E. Ibe, 1992: The impacts of sea level rise on the coastline of Nigeria [O'Callahan, J. (ed.)]. In: Global Climate Change and the Rising Challenge of the Sea. Proceedings of the IPCC Workshop at Margarita Island, Venezuela, 9-13 March 1992. National Oceanic and Atmospheric Administration, Silver Spring, MD, USA, 690 pp

Brooks, N., 2004: Drought in the African Sahel: longterm perspectives and future prospects. Working Paper 61, Tyndall Centre for Climate Change Research, University of EastAnglia, Norwich, $31 \mathrm{pp}$.

Buba, LF, 2014 Climate Change: in A.I. Tanko and S. B. Momale (Eds) Kano Environment, Society and Development. London \& Abuja, Adonis \& Abbey Publishers

Chappell, A. and C.T. Agnew, 2004: Modelling climate change in West AfricanSahel rainfall (193190) as an artifact of changing station locations. Int. J. Climatol., 24, 547-554.

Christensen, J.H., B. Hewitson, A. Busuioc, A. Chen, X. Gao, I. Held, R. Jones, R.K. Koli,W.-T. Kwon, R. Laprise, V.M. Rueda, L.Mearns, C.G.Menéndez, J.Räisänen,A. Rinke,A. Sarr and P.Whetton, 2007: Regional climate projections.Climate Change 2007: The Physical Science Basis. Contribution of Working Group I to the Fourth Assessment Report of the Intergovernmental Panel on Climate Change, S. Solomon, D. Qin, M. Manning, Z. Chen, M. Marquis, K.B. Averyt, M. Tignor and H.L. Miller, Eds., Cambridge University Press, Cambridge, 847-940.

Graetz, R. D., 1991. Desertification: a tale of two feedbacks. In Mooney $\mathrm{HA}$ et al. (eds) Ecosystem experiments. John Wiley and Sons, Chichester, p50-87

Grainger, A., 1996. Forest Environments. In Adams WM, Goudie AS, Orme AR (eds) The Physical Geography of Africa. Oxford University Press, Oxford p173-195

Gommes, R., J. du Guerny, F.O. Nachtergalle and R. Brinkman, 2005: Potential impacts of sealevel rise on populations and agriculture. Climate Change and Africa, P.S Low, Ed., Cambridge University Press, Cambridge, 191203.

Gonzalez, P., 2001: Desertification and a shift of forest species in the West African Sahel. Climate Res., 17, 217-228.
Haarsma, R.J., F.M. Selten, S.L.WeberandM. Kliphuis, 2005: Sahel rainfall variability and response to greenhouse warming. Geophys. Res. Lett., 32, Houghton, J. T., 2004. Global Warming: The Complete Briefing. 5 ed. Cambridge University Press.

Houghton, J., 2004. Global Warming. The complete briefing, Third edition. Cambridge: Cambridge University Press.

Hulme M, Dorherty R, Ngara T, New M, Lister D (2000) African Climate Change: 1900-2100. In: Desanker $P$ (ed) Africa and Global Climate Change. CR SPECIAL 8. Clim Res 17:145-168

IPCC, 2001: Climate Change 2001: Impacts, Adaptation, and Vulnerability. Contribution of Working Group II to the Third Assessment Report of the Intergovernmental Panel on Climate Change, J.J.McCarthy, O.F. Canziani, N.A. Leary, D.J. Dokken and K.S. White, Eds., Cambridge University Press, Cambridge, 1032 pp.

IPCC, 2007a: Climate Change 2007: The Physical Science Basis. Contribution of Working Group $I$ to the Fourth Assessment Report of the Intergovernmental Panel on Climate Change, S. Solomon, D. Qin,M.Manning, Z. Chen,M.Marquis, K.B.Averyt,M. Tignor and H.L.Miller, Eds., Cambridge University Press, Cambridge, 996 pp.

IPCC, 2007b: Climate Change 2007:Mitigation. Contribution of Working Group III to the Fourth Assessment Report of the Intergovernmental Panel on Climate Change, B. Metz, O. Davidson, P. Bosch, R. Dave and L. Meyer, Eds., Cambridge University Press, Cambridge, UK.

IRI, GCOS, DFID and ECA, 2006: A gap analysis for the implementation of the Global Climate Observing System programme in Africa, IRI (International Research Institute for Climate and Society) Technical Report, IRI-TR/06/1, $52 \mathrm{pp}$.

Jenkins, G.S., G.Adamou and S. Fongang, 2002: The challenges of modelling climate variability and change in WestAfrica. Climatic Change, 52, 263-286.

Jenkins, G.S.,A.T. Gaye and B. Sylla, 2005: Late 20th century attribution of drying trends in the Sahel from the Regional Climate Model (RegCM3). Geophys. Res. Lett., 32, L22705, doi:10.1029/2005GL024225.

IPCC, 2007: Summary for Policymakers. In: Climate Change 2007: The Physical Science Basis. Contribution of orking Group I to the Fourth Assessment Report of the Intergovernmental Panel on Climate Change [Solomon, S., D. Qin, M. Manning,

Z. Chen, M. Marquis, K.B. Averyt, M.Tignor and H.L. Miller (eds.)]. Cambridge University Press, Cambridge, United Kingdom and New York, NY, USA. 
Kowal, JM and Knabe, DT 1972. An Agroclimatological Atlas of the Northern States of Nigeria with explanatory notes. Ahmadu Bello University Press.

Maynard, K., J.-F. Royer and F. Chauvin, 2002: Impact of greenhouse warming on The West African summer monsoon. Clim. Dynam., 19, 499-514.

McCarthy, J. J., Canziani, O., Leary, N. A., Dokken, D. J., White K. S. (eds) 2001. Climate Change 2001: Impacts, Adaptation and Vulnerability. Contribution of of Working Group II to the third Assessment Report of the Intergovernmental Panel on Climate Change. Cambridge: Cambridge University Press.

McKinney, M. L. and Schoch, R. B. 1996. Environmental Science: Systems and Solutions. West Publishing Company

Mortimore, M.J. and W.M. Adams, 2001: Farmer adaptation, change and 'crisis'in the Sahel. Global Environ. Chang., 11, 49-57.

National Research Council, 2001. Climate Change Science, An Analysis of Some Key Questions. Washington, DC: National Academy Press.

Nicholson, S. E., 2001. Climatic and Environmental Change in Africa during the Last Two Centuries. Climate Research Vol 17: 123-144

Obasi, G.O.P., 2005: The impacts of ENSO in Africa. Climate Change and Africa, P.S Low, Ed., Cambridge University Press, Cambridge, 218230.

Olofin, EA, 2000. Environmental Hazards and Sustainable Agricultural Development in
Northern Nigeria In: Issues in Land Administration and Development in Northern Nigeriaa. Department of Geography, Bayero University, Kano Nigeria

Rowell, D.P., 2003: The impact of Mediterranean SSTs on the Sahelian rainfall season. J. Climate, 16, 849-862.

Schlesinger $\mathrm{WH}$, Reynolds JF, Cunningham GL, Huenneke LF, Jerrel WM, Virginia RA, Whitford WG (1990) Biological feedbacks in global desertification. Science 247: 10431048

Tarhule, A. and P.J. Lamb, 2003: Climate research and seasonal forecasting for West Africans: perceptions, dissemination, and use? B. Am. Meteorol. Soc., 84, 1741-1759.

Wang, G. and E.A.B. Eltahir, 2002: Impact of CO2 concentration changes on the biosphereatmosphere system of West Africa. Glob. Change Biol., 8, 1169-1182.

Wang, G., E.A.B. Eltahir, J.A. Foley, D. Pollard and S. Levis, 2004: Decadal variability of rainfall in the Sahel: results from the coupled GENESIS-IBIS atmosphere-biosphere model. Clim. Dynam., 22, 625-637.

Warren, R., N. Arnell, R. Nicholls, P. Levy and J. Price, 2006: Understanding the regional impacts of climate change: research report prepared for the Stern Review on the Economics of Climate Change. Tyndall Centre for Climate Change Research, Working Paper 90, University of East Anglia, Norwich, 223 pp. 